\title{
New Pedagogical Mediation Technologies in Accounting Education: A Discussion Based on Researches Published in the EnANPAD between 2005 and 2009
}

\author{
Vilma Geni Slomski ${ }^{1}$, Liliane Costa Jacobs Lames², Edilei Rodrigues de Lames², \\ José Carlos Marion ${ }^{3}$ \\ ${ }^{1}$ Àlvares Hairstyle School of Commerce Foundation-FECAP, São Paulo, Brazil \\ ${ }^{2}$ Adventist College of Hortolândia, São Paulo, Brazil \\ ${ }^{3}$ Pontifical Catholic University—PUC, São Paulo, Brazil \\ Email: vilma.geni@fecap.br, liliane.costa@unasp.edu.br, edilei.lames@ucb.org.br, jcmarion@usp.br
}

Received July 23 $3^{\text {rd }}$, 2013; revised August 23 $3^{\text {rd }}, 2013$; accepted August 30 ${ }^{\text {th }}, 2013$

\begin{abstract}
Copyright (c) 2013 Vilma Geni Slomski et al. This is an open access article distributed under the Creative Commons Attribution License, which permits unrestricted use, distribution, and reproduction in any medium, provided the original work is properly cited.
\end{abstract}

\begin{abstract}
This study aimed to characterize and analyze researches on new technologies in accounting education published in the EnANPAD during the period from 2005 to 2009. Therefore, an exploratory-qualitative research was carried out. Data were collected through document analysis. The concern of emphasizing the importance of the use and acceptance of new technologies in accounting education was one of the findings in evaluating such researches; another finding was the predominance of quantitative-descriptive approach; followed by the technique of questionnaire application in the collection and in the statistical analysis of the collected data. Limitations were noted concerning the lack of a greater articulation between the research theme, problem and objectives, as well as the lack of a larger theoretical and methodological consistency. Such difficulties may have affected the results and conclusions. Our conclusion is that difficulties and limitations of epistemological order can impair the validity and importance of the researches, and likewise also impair more scientific progress and contributions to the field of the knowledge at issue.
\end{abstract}

Keywords: Epistemology; Scientific Research; New Technologies; Pedagogical Mediation; Accounting Education and Research

\section{Introduction}

The scientific production relates to ways of elaborating systematized answers to the problems emerging from the world of the historical needs of the mankind, and these are rationalized through inquiries, queries and questions. The scientific explanation of the reality is based on a logic that clears up and provides the understanding of the type of relation established between facts, things and phenomena, unifying the vision of the world, and allowing the knowledge (Sánchez Gamboa, 2005). Science is thus "a manner of rational and objective interpretation of the universe, and fundamentally aims the production of knowledge with the purpose of submitting the natural forces to the will of the man in his struggle for survival” (Gomes, 2008: p. 3).

The innovations in the technological field, especially the information and communication technologies, are embedded in the daily routine of nearly all sectors, evidencing new ways of communicating, working and producing knowledge, thus causing transformations in the concepts of science, society and education. The still existing controversy on the use or not of new technologies in education is losing room in the academic environment, insofar studies, practices, investigations and new knowledge on their contribution to teaching, and learning processes are developed, resulting from new relations established with the knowledge upon using such technologies as mediation tools.

Studies analyzing the scientific production are frequent in all fields of knowledge, based on the idea that is indispensable to researchers to be alert to the nature of the knowledge created in their field of studies, as well as to the fundaments that guide their investigations. As highlighted by Bruyne et al. (1991), the advances of the sciences are not only "progressive", but also "reflexive". This means that the development of sciences, in addition to investigations that aim at their linear growth, depends on studies dedicated to the critical reflection on the knowledge produced in them.

Such ideas indicate that the production of knowledge is effective when meeting the requirements of the research formal quality, if not under the risk of reducing its transforming potential. The qualitative evaluation of the scientific production is part of the epistemology, which in the condition of meta-science performs the role of critically questioning the fundaments and principles of various sciences (Martins \& Théophilo, 2009). In this condition, it is understood as the methodic and reflexive study of science, of its organization, of its formation, of its functioning, and of intellectual products (Bunge, 1980). Thus, Santos (1989: p. 20) states that the epistemology "has to object the conditions and criteria of scientificity of scientific discourses". 
We thus notice that any scientific investigation requires steps to be followed, and the first one is the identification and formulation of the research problematic, followed by the clear elaboration of the objective that indicates the results to be achieved with the investigation. Within this scope, the other steps are natural consequences of these established ideas. When those basic issues are not a concern, the whole work can be jeopardized, and thus the scientific strictness and the fulfillment of quality standards of the conducted research.

Studies on the scientific production in the field of accounting education, more specifically on new technologies in pedagogical mediation, are becoming relevant in view of the fact that they can explain the condition and criteria of the scientific research conducted in that sphere. Studies carried out by Freitas (2005), Sloczinski and Chiaramonte (2005), Coutinho and Bottentuit Jr. (2010), among others, in regard to the use of technologies as mediators of the teaching and learning process, highlight the quality standard of the works and their validity. This concern has motivated the conduction of this research, which aims to answer the following question: What are the characteristics of researches on new technologies in pedagogical mediation in the field of accounting education published in the EnANPAD in the period between 2005 and 2009?

Considering this problem, a research was elaborated with the aim of analyzing and characterizing the researches on new technologies in pedagogical mediation in the field of accounting education published in the EnANPAD during the period from 2005 to 2009, in the pursuit of identifying limitations and methodological difficulties which could impair more contributions to researches and scientific progress in the field of knowledge at issue.

Studies trying to evidence the contributions of the scientific production, as well as the critical evaluation of conditions and criteria of scientificity of the produced discourses, were considered relevant. We expect that this study can contribute to deepening the knowledge and discussions about the methodological issues that permeate the scientific production, more specifically the aspects that evidence the stage of the scientific development and the fulfillment of quality standards of the works submitted in this field of knowledge.

\section{Theoretical Foundations}

The study and the critical evaluation of the conditions and criteria of scientific of scientific discourses and researches in various spheres have become relevant. In this section, we will discuss the concept of science, research and scientific knowledge, the theoretical-methodological assumptions of the scientific research, and the new technologies in pedagogical mediation.

\section{Science and Production of Knowledge}

The term science comes from the Latin scientia, and means knowledge or wisdom. Therefore, knowledge is the product of a confrontation of the world by the human being, which only fully takes place insofar he produces it, having it as a way of understanding the reality, and as such, it allows and improves his way of life, and not purely and simply "as a boring and uninteresting way of memorizing abstract and useless formulas for us to live and coexist in and with the world. Thus, the knowledge is a mechanism of understanding and transformation of the world" (Luckesi, 2005: p. 48).

In such terms, the central objective of the science is to understand and to explain the happenings and phenomena through theories. To Lakatos and Marconi (1991), Science is a set of attitudes and rational activities, oriented to the systematic knowledge with delimitated object, capable of being submitted to verification. Agreeing with this idea, Rudio (1986: p. 9) states that "science is done in a systematized way, with its own methods and specific techniques, in the pursuit of a knowledge that refers to the empirical reality".

In this study, we have started with the idea that the elucidative process of research problems, according to the criteria of strictness, analysis and interpretation:

Validates the characteristics of the scientific research, herein understood as one of the manners of the knowledge production. The accumulation of results of research processes is known as science or scientific knowledge, which once systematized becomes the scientific and academic knowledge, regarded as one of the most significant heritages of the mankind (Sánchez Gamboa, 2005: p. 3).

Within this sphere, the scientific method emerges from the need of finding answers through ways that can be proved, as a manner of organizing the thought to attain the most proper way to know and to control nature. The reality starts to be perceived from the viewpoint of science, through a guiding criterion, an explicatory principle that clears up and allows the understanding of the type of relation established between facts, things and phenomena, unifying the vision of the world. This type of knowledge is opposed to the disordered, broken up, fragmented form, as occurred in the subjective and uncritical vision of the common sense. Thus, producing knowledge means more than launching ideas, it means to provide the knowledge with a meaning in the attempt to interpreting the world, as opposed to a utilitarian attitude in regard to the production of knowledge (Gomes, 2008).

These ideas allow saying that the scientific production is one of the ways of elaborating systematized answers to the emerging problematic, "came out from the world of historical needs of the mankind, and rationalized through inquiries, queries and questions” (Sánchez Gamboa, 2005: p. 3). The scientific research is thus a strategy to solve the problems of the practical life.

When we talk about science and production of the scientific knowledge, firstly we need to talk about the philosophy of science (Hervada, 2008) or about the study of the nature of knowledge. The analysis of the scientific production has historically achieved a specific field called epistemology. The term epistemology comes from the Greek composition of episteme (knowledge) and logos (reason, explanation), and means the study of the nature of knowledge, its rationale and limits (Audi, 2004). These are dimensions about the possibility, sources, essence, and criteria of validity of a systematic knowledge (Episteme), which for having the obligation of explaining and justifying the methods or ways and manner of elaborating its results are different from the knowledge based on traditions and on the common sense (Sánchez Gamboa, 2005).

However, to say that science differs from other forms of knowledge means to admit the logical, methodic and theoretical nature of the science, as discussed in the previous paragraphs. It is undeniable that the researcher's work invariably reflects his 
vision of the world, i.e., his experience of life, as well as the theoretical and methodological assumptions that guide him, and, on the other hand, the existence of different visions, and thus of different epistemological paradigms, as explained by Sánchez Gamboa (1989: p. 102), “the 'objectivity' — cognitive process focused on the object, intended by the empirical-analytical approaches, and different from 'subjectivity' - process focused on the subject of phenomenological-hermeneutical approaches, and the 'concreteness'-focused on the dynamic subject-object relations intended by dialectical”.

In an analysis of the scientific production in the Accounting field, Theóphilo and Iudícibus (2005) point out that it is more common to find studies focusing on this production guided by the bibliometrics than by epistemology. Foreign studies and researches of critical-epistemological nature were conducted in the Accounting field with the purpose of following up this production, including the studies of Kasanem, Lukka and Siitonen (1993), Keating (1995); Mattessich (1996); Kaplan (1998); Young (1999); Feliu and Palanca (2000); Baxter and Chua (2003); among others.

Concerning national studies on Accountancy and areas alike, we can mention Theóphilo and Iudícibus (2005); Nossa, Fiório and Sgarbi (2006); Matias et al. (2007); Ribeiro Filho et al. (2007); Zanchet (2007); Gabriel, Pimentel and Martins (2009); Nascimento, Junqueira and Martins (2009); Porton and Loch (2009); among others. These studies had their start in the understanding that it is indispensable to researchers to be alert to the nature of the knowledge generated in their field of study, as well as to the fundaments that guide such investigations.

Therefore, in this study, we discuss the main scientific methods, divided into: inductive (empiricist theory), deductive (rationalist theory), and dialectical (materialist theory), which are approached in more detailed as follows.

\section{Main Scientific Approaches}

With the intent of subsidizing the discussions and analysis of the intended scientific production, and to fundament the methodological selection adopted by researches, we have discussed the empirical-positivist, idealist-rational and materialisticdialectical approaches.

The positivism represents an advance and "a rupture with the metaphysical conceptions based on the religious conceptions, since it rejects all the previous assumptions launching new bases for the production of the knowledge" (Gomes, 2003: p. 08). Its main founder Augusto Comte, in his writings already values the fact, the experience and the proof to provide the treatment of social phenomena with a scientific shape, i.e., he manifests his unreserved trust in science.

The base of constitution of scientific knowledge and methodological assumptions in the positivism is stressed by characteristics according to which the knowledge should be obtained from the observation of the inductive character, only considering that the experience and the empirical text can be the true source of knowledge, and such domains are the judgments that have scientific value. Sánchez Gamboa (2009), when referring to the topic, says that the positivist paradigm, in the pursuit of the guarantee of objectivity and neutrality, uses techniques of collection, treatment and analysis of typically quantitative data, using statistical measurements and procedures. Therefore, the strictness of this kind of statistical analysis and controlled observation is supposedly the guarantee of objectivity, i.e., the researchers subjects should be care to be objective, not allowing at all that the association of ideas, interpretations and values interfere with the results of their work. To Gomes (2003: p. 14) the positivism

Privileges the treatment of themes by defining independent, dependent variables, or variables defined as features, functions or roles, having the concept of cause as the fundamental axle. The causal relations are explained through the experiment, systematization and control of empirical data, privileging statistical and theoretical analyses.

These definitions and understandings make it clear that the basic assumption of the science for the positivist paradigm is the pursuit of phenomena causes, and the source of knowledge is the captured object itself as presented to the researcher.

In turn, the idealism regards the idea, the thought, the consciousness as priority-it understands that the knowledge has the origin in perceptions and intuitions of the subject, that it has a rational, perceptive and intuitive basis. According to Nonaka and Takeushi (1997), this has to do with the existence of a culture of the knowledge, in which there is a separation between the subject (knowing person) and the object (known object), based on the Cartesian postulation of the doubt, expressed in the famous phrase: I think, therefore I am, and thus based on an strict analytical methodological basis. This theory regards the reason, the human capacity of thinking, evaluating and establishing relations among certain elements, as the main source of knowledge - it points out to the primacy of the subject or of his activity in relation to the object, since it takes the reason, i.e. the human capacity of thinking, evaluating and establishing relations among certain elements, as the main source of knowledge. The idea of cause, for instance, would be situated in the reason, and would be from such reason that it could be possible to produce a safe knowledge of the reality. Mora (1996: p. 344) classifies as idealist "all and every doctrine (sometimes simply all and every attitude) according to which the most fundamental thing is the one because of which human actions should be supposedly conducted - these are the ideals-realizable or not, but almost always imagined as realizable".

Briefly, we can say that the objective idealism rejects the idea that the primary is the human individual consciousness, since it considers the supreme idea, the objective consciousness, the absolute spirit as the primary basis of existence. This philosophical current (re)conducts all the existence to the thought, either in reality, or in the knowledge. Triviños (2006: p. 19) explains that all the idealistic positions recognize the principle of though over the matter, and the later is presented as secondary.

The dialectic-historic materialism is defined as a method of interpreting the reality based on its social-economic and cultural factors, having as background the criticism to the static view of the reality assumed by other lines of through such as the positivism and the rationalism, since the hide the dynamic, historic and systemic nature of the reality (Gomes, 2003). The dialectic materialism, in turn, has the Marxism as philosophical basis, and according to it, the matter comes first, and the consciousness tries to reflect on the objective reality. It incorporates, as the fundamental category, the social practice of individuals that is responsible for the transformation of nature and of the social life.

The main concern of this current of thought resides in the deep pursuit to know the history as a way of understanding the 
present. The materialism states that the knowledge is produced in the picture of interaction between subject and object. Under such perspective, the products of science are the results of the interrelations with the reality, based on the social practices (Carvalho et al., 2000). The knowledge is born from the interrelation (language) between people, who situated in time and space, transmit and get closer to a certain type of historically accumulated knowledge (culture/fact of knowing) (Devechi, 2008). Being the science itself a social practice, "its products would not be destitute of assumptions given above all by culture or by the predominant ideology in a given historic period" (Carvalho et al., 2000: p. 6).

To Gomes (2003: p. 17), researches based on the historicaldialectical materialism are characterized by the criticism and are concerned with:

Unveiling the contradictions presented by the real, expressed in the conflict of interpretations and interests, to then proposing ways to overcome, with the meaning of transforming such reality by redeeming its historical dimension. The epistemological fundaments of such researches are found in the internal logic of the process, and in methods that unveil the dynamics and the contradictions of phenomena, as well as the man/nature, reflection/ action, and theory/practice relation.

Shortly, the researches based on this paradigm use methods that try to unveil the internal logic of phenomena, interconnections, dynamism, contradictions, as well as the man/nature, reflection/action and theory/practice relation.

This study attempts to critically analyze the theoreticalmethodological trends or scientific paradigms present in researches developed in the field of the accounting education, more specifically new technologies in pedagogical mediation, analyzing the existence of the articulation between the technical-instrumental, methodological and theoretical levels, as well as identifying philosophical assumptions that allow the identification of ideological perspectives that, as assumptions, relate the research practice with visions of the world and the interests of the researchers.

\section{Concept and Studies about Digital Media in Pedagogical Mediation}

The constant economic, social and cultural changes require us to rethink education in various levels, especially in the university level. Currently, social communication is becoming virtual, with its own languages that, in a certain way, minimize physical and geographic distances defining new manners of interaction. Media and technologies point out to new times, and new languages are created, either material, formal or programmed.

The studies of Pierre Lévy, one of the most important advocates of artificial intelligence and collective learning, go towards the same direction, To this author "the main problem of the dialogue with computers is the difference between formal languages, which govern the behavior of machines and the natural languages used and understood by men in their routine life” (Lévy, 1999: p. 31). Grinspun (1999: p. 49) understands the digital media as "the scientific knowledge transformed into technique that, in turn, will expand the possibility of producing new scientific knowledge", and therefore it can be said that it is a set of knowledge, information and skills that taste the "scien- tific invention that is operationalized through different methods and techniques, and that is used in the production and consumption of goods and services” (Grinspun, 1999: p. 51).

On the other hand, Reis (2009) defines the educational technology as the "set of procedures and techniques aiming to make education and learning processes 'easy' with the use of means (instrumental or symbolic) and their consequent cultural transformations". After all, it is necessary to incorporate the NTICs (New Technologies of Information and Communication) in the pedagogical mediation in order to show how much they are really important in the process of improving education, in special the superior (college) education.

In this research, we understand digital media according to Santaella (1996: p. 38) who says "the term media in the plural aims to highlight the different features of each medium, to characterize the culture that is born in the transits, exchanges and mixtures among different communication means". Thus, a system of expression and communication that allows the integration between thought and languages in interaction with the environment where we live is called media and technologies.

The media commonly used by individuals in the information and communication society includes telephone, satellites of TV broadcast, electronic books, facsimile devices, CD ROM, and laser disks, which form a set of technological innovations of information and communication, the so-called TICs (Technologies of Information and Communication), etc. Media are configured into hypermedia, multimedia, websites, digital tools such as the chat, discussion groups or lists, forums, video, and videoconference, electronic mail, and other digital resources and languages.

However, to that end, it is necessary to bear in mind how the NTICs are being incorporated to the homes, offices and schools, changing habits and customs, thus showing how the ideal relation should be in the educational context: "technology should be used as an instrument at the service of education, in order to improve the students learning process" (Guimarães, 2005: p. 23). Only having the NTICs resources is not enough, it is necessary to know how to use them in pedagogical mediation, so that NTICs can really be an instrument that adds quality and enhancement to the curriculum of future professionals.

In such incorporation, the teacher needs to be aware of his/ her role, of how the interaction with the students should be, and to that end he/she shall have the attitude of partnership and coresponsibility with the student in his/her learning process. Thus, the pedagogical mediation as an "attitude, behavior of the teacher who places him/herself as a mediator and motivator of learning, with the willingness to be a bridge between the knowledge and the apprentice” (Masetto, 2003).

The pedagogical mediation highlights the student role as apprentice, while strengthening him/her as the actor of activities that allow him/her to learn and help him/her to reach his/her goals, in addition to giving a new color to the teacher's role and to the materials he/she uses to work, thus allowing to grow and develop as a teacher.

The teacher does not need to be limited to the classroom to teach his/her students, with the support of new technology (NTICs), he/she can expand this activity outside the classroom, with the collective construction of knowledge taking place. According to Masetto (2003), the teacher can teach by using the Internet, CD-ROM, hypermedia, multimedia, websites, tools such as the chat, discussion groups or lists, forum, video and videoconference, electronic mail and other digital resources and 
languages that are currently available, significantly collaborating to make the education process more efficient and effective, in addition to the use of computers that have various tools that enrich the learning process.

A recent study of the Caxias do Sul University-UCS, concerned with the use of digital media in the knowledge construction process, and "the need of reflecting on the educational possibilities mediated by technologies, gave rise to a seminar of studies-SEMATIC (Seminar of Learning Environments mediated by Technologies of Information and Communication)" (Sloczinski \& Chiaramonte, 2005: p. 74). Such event had the aim of "qualifying teachers to create teaching strategies that use information and communication technology, to develop significant learning in their field of activities, within the sphere of the UCS".

Initiatives such as this allow a bigger reflection on a higher integration of technologies and methodologies to work with the verbal, written and audiovisual resources (Moran, 2000). However, this behavior does not means that it is necessary to change already know processes by IC technologies, only because multimedia is in fashion. Every resource should aim to improve the pedagogical practice, as facilitators of the collaborative teaching and learning process. Traditional didactics can be integrated to new media in order to allow the mediation between the teacher, the student and the knowledge.

This understanding indicates the practical realization of Lévy (1999) when he says that the essential is found in the new style of the pedagogical practice, which favors both personalized learning and network learning. Within this context, the teacher becomes an active agent awakening the collective intelligence of groups of students, instead of being the direct "provider" transmitter of school contents.

It is important for teachers to be able to elaborate strategies that allow students to keep a continuous interaction with the support and learning environments, which awake the interest for the pursuit of new knowledge, leaving the passive position of mere receptors of what is transmitted by teachers, to an active position, which makes them not being satisfied only with what is said by teachers, but rather pursue other ways of thinking and other reflections about the subject, in order to build their own conceptions and opinions. Thus, Sloczinski and Chiaramonte (2005: p. 83) highlight that the change of the pedagogical practice can allow reaching the objective of "constructing how to know, aggregating knowledge, organizing and systematizing the social, scientific and human knowledge”.

However, it is necessary to prepare both teachers and students to immerse in such change of traditional education practices, changing to education practices more based on the use of technologies, because there are significant different perceptions between teachers and students, as shown by the study of Coutinho and Bottentuit Jr. (2010) who analyzed the perspective of teachers and students in a Portuguese Professional School, about the introduction of a E/B-Learning model (distance education for professionalizing courses), and perceived that the perspectives, both positive and negative, of students and teachers researched in that school are very different.

However, when studies on NTICs in the pedagogical mediation of accounting education are checked, we notice the relevance and enrichment of the teaching-learning process. Eyerkaufer, Fietz and Domingues (2006) conducted a study on the information technology in teaching accountancy, in two institutions of Santa Catarina and concluded that there is little divul- gation so that teachers and students can know how exactly to use and when to use technology in the course of Accounting Sciences;

Another study conducted by Brun, Dall'Asta and Dotto (2010) proposed to develop a computer tool providing more efficiency and reliability to the teaching process of Analysis of Financial Statements, concluding that the developed software "Easy Analysis" is a useful tool that uses indexes, because the software does not only facilitate the calculation process, but also, because it is an academic took, provides information that clear up the basic concepts of each analysis index.

We can also highlight other authors such as Andrade (2002), Resende (2003), Cornachione Jr. (2004) who have done works approaching the introduction and/or use of technological resources in the teaching-learning process in the accounting education, proving that the accountancy teaching by using such resources used as a tool that help the teacher can positively contribute to the explanation of subjects addressed during the course.

The continuous pursuit of new Knowledge is one of the drivers of the economic development and one of the pillars of education. The college teacher will have to get updated and to pursue new ways of building knowledge, in order to develop new competences and to be in conditions to meet the requirements and challenges imposed by the world of labor.

College education professionals should follow the technological development and the new ways of thinking and interpreting the reality, otherwise they are jeopardized of becoming obsolete. Education institutions require professionals capable of interpreting, elaborating, transforming and creating-people with technical, scientific, social and behavioral skills. The use of new technologies increases the creative capacity of students by making them "walk" with autonomy, pursuing the self-formation and self-development.

\section{Methodology}

This research is characterized as an exploratory-qualitative research, which tries to outline the profile of researches conducted about new technologies in the pedagogical mediation of the accounting education, published by the EnANPAD, between 2005 and 2009.

This kind of research also allows surveying the characteristics of the investigated subject, leading the researcher to find out the new focus, perceptions and terminologies, significantly contributing to modify his/her own way of thinking and acting (Pinsonneault \& Kraemer, 1993). According to Minayo (2008), the exploratory research in conformity with the qualitative approach has the aim of answering particular questions, working with a universe of meanings, reasons, aspirations, beliefs, values, attitudes, among others, that is, a qualitative research highlights the process, the critical reflection on data, and the personal interpretation.

This study was limited to the works published in the EnANPAD, between 2005 and 2009, and submitted and approved by the Academic Division of "Education and Research on Administration and Accountancy-EPQ”, along with the works presented in the EnEPQ, which was only two editions, 2007 and 2009; they address the topic of new technologies in the mediation of the accounting education. The timeframe was decided as to cover two editions of the EnEPQ, and is a plausible range for the studies. 
The selection of the publications submitted to this event was done because the EnANPAD_ANPAD Meeting - is one of the major events of the scientific and academic community of administration in the country, also being a great stimulator of the scientific production, and the past three years, at each event, approximately three thousand works were submitted to appraisal in various theme areas, and approximately eight hundred works were actually presented. In addition of having a very satisfactory evaluated concept according to CAPES Foundation, of the Ministry of Education.

Data were collected through the analysis of documents which, according to Ferrari (1982: p. 224), "is done based on finished sources that did not received an analytical treatment, or if this happened, can still be reinforced, or can still receive a new reformulation according to the research objectives”. The criteria used to classify the articles were as follows: 1) addressing the topic of new technologies in the pedagogical mediation of the accounting education process with a broad meaning, not only focusing on one technology or its importance; 2) having been published in the period 2005 to 2009, in the EnANPAD or EnEPQ. Therefore, the articles included in the aforementioned editions were selected, by searching in the events annals with the following keywords: college education teaching, pedagogical mediation, new technologies, accounting education, accountancy teaching, technologies, college education, mediators, accounting sciences, NTIC, didactic-pedagogical.

Only works belonging to the EPQ academic division of the EnANPAD and to the EnEPQ were focused in those searches. However, these procedures were not enough to make the final work selection, because not all of them referred to new technologies in accounting education. In those cases, the abstract was read, and if there were still remaining doubts, the results as well as the conclusions were briefly read too. We tried to meet the parameters by using such procedures. This selection procedure resulted in only four articles.

After such article selection procedures, we started to build the data collection instrument. The instrument was divided into two parts, and the first one was composed of the theme, problem and objective of the work. The second part is composed of the research methodology, subdivided into types and approach of the research, data collection and analysis techniques, thus allowing an in-depth and critical evaluation of the articles, as shown in the Table 1.

Data were interpreted through their contents analysis, as proposed by Bardin (2004) when he says that this takes places in three chronological moments, namely: 1) pre-analysis; 2) exploration of the material; 3 ) treatment of the results obtained and interpretation. Therefore, in this research, data were divided into categories and subcategories, and the interpretative analysis was carried out, as presented in the following section, in order to identify the existing relations, features of each article, methods, approach, etc. in addition of identifying the investigation problems, attaining the following results.

\section{Results and Discussions}

The results are presented according to the data collection instrument, and were oriented towards the theoretical and methodological issues of the submitted articles in the field of Administration and Accountancy Teaching and Research (EPQ) and to the EnEPQ, where we have tried to examine the types and approaches of research, methods, techniques and proce-
Table 1.

Data collection instrument.

\begin{tabular}{cc}
\hline \multicolumn{2}{c}{ CATEGORIES OF ANALYSIS } \\
\hline \multicolumn{2}{c}{ Theme } \\
\hline Problem \\
\hline $\begin{array}{c}\text { Objective } \\
\text { Type of research }\end{array}$ & $\begin{array}{c}\text { Exploratory, Bibliographic, Descriptive, } \\
\text { Case study. }\end{array}$ \\
$\begin{array}{c}\text { Research approach } \\
\text { Techniques and procedures } \\
\text { of data collection }\end{array}$ & $\begin{array}{c}\text { Form, Questionnaire, Interview, Focus } \\
\text { group, Document Analysis, etc. }\end{array}$ \\
$\begin{array}{c}\text { Techniques and procedures } \\
\text { of data analysis }\end{array}$ & $\begin{array}{c}\text { Statistics, Mathematics, Contents analysis, } \\
\text { other techniques. }\end{array}$ \\
\hline
\end{tabular}

Source: Authors.

dures for the data collection and analysis.

\section{A Profile of the Investigated Works: The Integration between Theme, Problem and Objective}

According to the information in Table 2, article 01 analyzed was developed in the discipline of General Accountancy II, and has focused on the use of educational technology as a way of discussing and deepening the contents of such discipline. As for the integration between the title, problem and objective, we notice the delimitation and a major focus of the objective as for the possibility of students interaction created by new technologies. This fact becomes evident in the conclusions of the work that reveal that the association between educational technologies, cooperative learning and the Salesian style of teaching create interaction opportunities, are applicable to the basic Accountancy teaching, with possibility of extending this methodology to other disciplines of the Accounting Sciences, resulting in a more effective and efficient learning (Neves Jr., 2006; Medeiros, 2006; Batista, 2006).

Article 2 addressed the use, importance and frequency of utilization of new technologies in accounting education. We observe that this research has investigated the perception of students about the importance of having Information Technology competences for their professional qualification. As for the integration between the title, problem and objective, data indicate the absence of the problem aspect, however, there is a certain adequacy to the objective. Results indicate that more than $50 \%$ of the investigated students value and regard the use of new technologies in the learning process as important (Gomes \& Gianoto Jr., 2007).

Article 3 has investigated the role of the information technology in the formation of the Accounting Sciences Professional, having as target teachers teaching the discipline of Information Systems and Information Technologies. It tried to get to know their perceptions about the importance of the student developing such competences, as well as the way teachers try to develop the student in such field. As for the integration between title, problem and objective of "measuring the importance given by teachers of the accounting sciences courses to the competences regarding Information Systems and Information Technologies for the professional qualification of accountants, and examining how such competences are developed in their disciplines", Table 2 data indicate the absence of the problem aspect, and of the limits of the study focus, because the title indicates 
Table 2.

Integration between theme, problem and objective in analyzed researches.

\begin{tabular}{|c|c|c|c|c|}
\hline & Article 1 & Article 2 & Article 3 & Article 4 \\
\hline Theme & $\begin{array}{l}\text { Cooperative Learning and Educational } \\
\text { Technology in the Discipline of General } \\
\text { Accountancy II of the Course of Accounting } \\
\text { Sciences of the Catholic University of Brasília } \\
\text { —in the Salesian teaching style }\end{array}$ & $\begin{array}{l}\text { Accountancy and the New } \\
\text { Information Technologies: a } \\
\text { study on the perceptions of } \\
\text { the undergraduate students of } \\
\text { Accounting Sciences }\end{array}$ & $\begin{array}{l}\text { The Role of Information } \\
\text { Technology of the Accounting } \\
\text { Sciences Professional: a study } \\
\text { on the perceptions of the IES } \\
\text { teachers of the city of Rio de } \\
\text { Janeiro }\end{array}$ & $\begin{array}{l}\text { Virtual Environments of } \\
\text { Learning the Free Code as } \\
\text { Support to the Traditional } \\
\text { (Live) Education in the Field of } \\
\text { Applied Social Sciences: a case } \\
\text { study in a college education } \\
\text { institution }\end{array}$ \\
\hline Problem & $\begin{array}{l}\text { The problem situation found is related to the } \\
\text { difficulties in incorporating new technologies } \\
\text { to the basic accountancy teaching, since this } \\
\text { discipline is taught in the } 2 \text { nd school semesters, } \\
\text { and at this point the students had little contact } \\
\text { with interaction dynamics and philosophy of } \\
\text { the cooperative learning group. }\end{array}$ & Not informed & Not informed & $\begin{array}{l}\text { What are the college students' } \\
\text { attitudes before the existence of } \\
\text { virtual environments available } \\
\text { in the web to support the } \\
\text { traditional education. }\end{array}$ \\
\hline Objective & $\begin{array}{l}\text { Show the applicability of the contents of the } \\
\text { Cooperative Learning group and Educational } \\
\text { Technology in the Discipline of General } \\
\text { Accountancy II of the Course of Accounting } \\
\text { Sciences of the Catholic University of Brasília. }\end{array}$ & $\begin{array}{l}\text { Examine whether the } \\
\text { students of the Accounting } \\
\text { Sciences courses perceive } \\
\text { the importance of getting } \\
\text { competences of Information } \\
\text { Technology for their } \\
\text { professional qualification. }\end{array}$ & $\begin{array}{l}\text { Measuring the importance } \\
\text { given by teachers of the } \\
\text { accounting sciences courses to } \\
\text { the competences regarding } \\
\text { Information Systems and } \\
\text { Information Technologies for } \\
\text { the professional qualification of } \\
\text { accountants, and examining } \\
\text { how such competences are } \\
\text { developed in their disciplines. }\end{array}$ & $\begin{array}{l}\text { 1st moment-Presenting a case } \\
\text { study of the implementation of } \\
\text { a Virtual Learning Environment } \\
\text { (VLE); 2nd moment- } \\
\text { Establishing what are the main } \\
\text { attitudes of IES students in } \\
\text { relation to the importance, } \\
\text { utilization and satisfaction } \\
\text { regarding the VLE. }\end{array}$ \\
\hline
\end{tabular}

Source: Research data.

the perceived importance, but the objective indicates that, in addition to that, they would try to get to know how teachers teach such discipline.

Such indications reveal the difficulties to elaborate an article based on these two problems or concerns of the authors. However, the conclusions presented indicate that, through the research, it was possible to identify the need of restructuring the contents of the disciplines at issue, with the aim of integrating the topics of Information Systems and Information Technology, in order to meet the new needs of the accounting field professionals. (Gianoto Jr. et al., 2007).

Article 4 has investigated the perception of students about the use of virtual learning environments, and thus has studied their implementation, and appraised the satisfaction with and the utilization of the implemented system. As for the integration between title, problem and objective, data reveal the lack of adequacy to the study object "Virtual Environments of Learning the Free Code with the support to the traditional (live) education in the field of Applied Social Sciences”, and as for the desired results "implementation of a Virtual Learning Environment (VLE) and appraisal of the importance, utilization and satisfaction of students in regard to the VLE”. When observing the problem aspect, the difficulty to overcome is related to the behavior of students in view of the VLE. "What are the college students' attitudes before the existence of virtual environments available in the web to support the traditional education".

This research presents as conclusion the records of a high degree of agreement amongst students on the usefulness and importance of VLE, as support to traditional education, because their use exceeds the traditional teaching way and increases the students' learning level (Carvalho Neto \& Takaoka, 2009). However, it is highlighted that conclusions should always be supported by results, which are attained through clear objectives and specific methods.

The Table 2 summarizes the analyses so far conducted, high- lighting the existing integration between theme, problem and objectives of the analyzed researches.

We can also highlight that, as for the identification and formulation of the research problem, two of these studies do not present the research issue, and two present it in a limited manner, since we can identify it in the text, even though it is not in the shape of a question. The scientific production problematic is addressed by Martins and Theóphilo (2009) who understand that the elaboration of a research is started with the problem, and is the pursuit for its solution that guides the whole investigation logics. This means to say that the fundamental objective of the reality diagnosis or analysis is to get to know the problem situation and to transform it. The objectives have the function not only of investigating the cause of a given fact, the concrete social situation, but also to bring out results that serve to solve the problem, in order to make it possible to work in a more effective way.

In regard to the objectives, we observe that they are formulated in all the analyzed articles. However, inadequacies are observed in regard to their elaboration, their relation with the research theme and problem. Martins and Theóphilo (2009) observe that the research objectives should inform what for the study is proposed, i.e., what are the results intended to be attained or what contribution the research will effectively provide. The objectives should be articulated to the research theme and problem. The propositions of objectives should start with a verb in the infinitive form, and such verb should indicate an measurable action. However, we observe in the analyzed articles that such aspects are not entirely accomplished, in a way jeopardizing the methodological rigor and the attainment of the best quality standards of the accountancy research.

\section{An Analysis of the Methodological Aspects of the Investigated Works}

Table 3 presents the methodological aspects found in the 
Table 3.

Documental analysis of the articles.

\begin{tabular}{|c|c|c|c|c|}
\hline & Article 1 & Article 2 & Article 3 & Article 4 \\
\hline Theme & $\begin{array}{l}\text { Cooperative Learning and Educational } \\
\text { Technology in the Discipline of General } \\
\text { Accountancy II of the Course of } \\
\text { Accounting Sciences of the Catholic } \\
\text { University of Brasília—in the Salesian } \\
\text { teaching style. }\end{array}$ & $\begin{array}{l}\text { Accountancy and the New } \\
\text { Information Technologies: a } \\
\text { study on the perceptions of } \\
\text { the undergraduate students } \\
\text { of Accounting Sciences. }\end{array}$ & $\begin{array}{l}\text { The Role of Information } \\
\text { Technology of the } \\
\text { Accounting Sciences } \\
\text { Professional: a study on the } \\
\text { perceptions of the IES } \\
\text { teachers of the city of Rio de } \\
\text { Janeiro. }\end{array}$ & $\begin{array}{l}\text { Virtual Environments of Learning the } \\
\text { Free Code as Support to the Traditional } \\
\text { (Live) Education in the Field of Applied } \\
\text { Social Sciences: a case study in a college } \\
\text { education institution. }\end{array}$ \\
\hline Problem & $\begin{array}{l}\text { The problem situation found is related } \\
\text { to the difficulties in incorporating new } \\
\text { technologies to the basic accountancy } \\
\text { teaching, since this discipline is taught } \\
\text { in the 2nd school semesters, and at this } \\
\text { point the students had little contact with } \\
\text { interaction dynamics and philosophy } \\
\text { of the cooperative learning group. }\end{array}$ & Not informed & Not informed & $\begin{array}{l}\text { What are the college students' attitudes } \\
\text { before the existence of virtual } \\
\text { environments available in the web to } \\
\text { support the traditional education. }\end{array}$ \\
\hline Objective & $\begin{array}{l}\text { Show the applicability of the contents } \\
\text { of the Cooperative Learning group and } \\
\text { Educational Technology in the } \\
\text { Discipline of General Accountancy II } \\
\text { of the Course of Accounting Sciences } \\
\text { of the Catholic University of Brasília. }\end{array}$ & $\begin{array}{l}\text { Examine whether the students } \\
\text { of the Accounting Sciences } \\
\text { courses perceive the } \\
\text { importance of getting } \\
\text { competences of Information } \\
\text { Technology for their } \\
\text { professional qualification. }\end{array}$ & $\begin{array}{l}\text { Measuring the importance } \\
\text { given by teachers of the } \\
\text { accounting sciences courses } \\
\text { to the competences regarding } \\
\text { Information Systems and } \\
\text { Information Technologies for } \\
\text { the professional qualification } \\
\text { of accountants, and } \\
\text { examining how such } \\
\text { competences are developed } \\
\text { in their disciplines. }\end{array}$ & $\begin{array}{l}\text { 1st moment - Presenting a case study } \\
\text { of the implementation of a Virtual } \\
\text { Learning Environment (VLE); 2nd } \\
\text { moment-Establishing what are the } \\
\text { main attitudes of IES students in } \\
\text { relation to the importance, utilization } \\
\text { and satisfaction regarding the VLE. }\end{array}$ \\
\hline
\end{tabular}

Issues to check in relation to the methodological aspects

\begin{tabular}{|c|c|c|c|c|}
\hline $\begin{array}{l}\text { Type of } \\
\text { research }\end{array}$ & $\begin{array}{l}\text { The research type is initially indicated } \\
\text { in the abstract, the authors report that } \\
\text { the research is developed by means of a } \\
\text { case study. In the methodology, the } \\
\text { research is classified as applied, } \\
\text { qualitative, exploratory, bibliographic, } \\
\text { documental, and case study. }\end{array}$ & $\begin{array}{l}\text { This information is explicit in } \\
\text { the methodology, there is } \\
\text { indication that the study } \\
\text { counted on a bibliographic, } \\
\text { documental and field survey. }\end{array}$ & $\begin{array}{l}\text { There is indication that the } \\
\text { study counted on a } \\
\text { bibliographic, documental } \\
\text { and field survey. }\end{array}$ & $\begin{array}{l}\text { The research type is initially indicated in } \\
\text { the abstract. There are indications that } \\
\text { the study was divided into two moments, } \\
\text { firstly with the conduction of a case } \\
\text { study; secondly, with the conduction of } \\
\text { a descriptive-quantitative research. In } \\
\text { other sections, there is information that } \\
\text { the research would be a field survey. }\end{array}$ \\
\hline $\begin{array}{l}\text { The target- } \\
\text { population is } \\
\text { characterized? }\end{array}$ & $\begin{array}{l}\text { It was not possible to identify which } \\
\text { was the target-population of this } \\
\text { research. }\end{array}$ & $\begin{array}{l}\text { The abstract evidences that } \\
\text { the perception of students of } \\
\text { federal public universities of } \\
\text { Rio de Janeiro was examined, } \\
\text { and that } 283 \text { valid } \\
\text { questionnaires were } \\
\text { collected. In the } \\
\text { methodology, it is identified } \\
\text { that the questionnaire was } \\
\text { answered by students in the } \\
\text { classroom, with the support } \\
\text { of the UFRJ and UFF } \\
\text { teachers, obtaining } 283 \text { valid } \\
\text { observations. }\end{array}$ & $\begin{array}{l}\text { In the abstract, it is reported } \\
\text { that the population is } \\
\text { composed of teachers of the } \\
\text { two public college education } \\
\text { institutions in the state of Rio } \\
\text { de Janeiro. In the item } \\
\text { methodology, there is the } \\
\text { information that } 8 \text { in-depth } \\
\text { interviews were conducted } \\
\text { with the teachers of both } \\
\text { public college education } \\
\text { institutions in the city of Rio } \\
\text { de Janeiro. }\end{array}$ & $\begin{array}{l}\text { There is indication of the IES selected, } \\
\text { its location, number of students and } \\
\text { teachers, courses offered, educational } \\
\text { background of its teachers. }\end{array}$ \\
\hline $\begin{array}{l}\text { The sampling } \\
\text { plan is well } \\
\text { defined and } \\
\text { justified? }\end{array}$ & $\begin{array}{l}\text { It was not possible to identify the } \\
\text { sample descriptions. }\end{array}$ & $\begin{array}{l}\text { It was not possible to } \\
\text { identify the sample } \\
\text { descriptions. There is } \\
\text { indication that the sampling } \\
\text { was done because of the } \\
\text { access. }\end{array}$ & $\begin{array}{l}\text { Only indications that the } \\
\text { interviewees selection was } \\
\text { done considering the access } \\
\text { and upon judging them. }\end{array}$ & $\begin{array}{l}\text { In the abstract, we have identified } \\
\text { information that the sample was } \\
\text { composed of } 123 \text { undergraduate } \\
\text { students of the administration and } \\
\text { advertisement courses, and the selection } \\
\text { was done through a non-probabilistic } \\
\text { sampling by judgment. } \\
\text { In the methodology item, there was } \\
\text { information saying that the selection } \\
\text { was not done by raffling off the } \\
\text { respondents, which makes the sample } \\
\text { non-probabilistic. } 128 \text { students were } \\
\text { interviewed, generating a final total of } \\
123 \text { valid questionnaires. }\end{array}$ \\
\hline
\end{tabular}




\begin{tabular}{|c|c|c|c|c|}
\hline $\begin{array}{l}\text { Does the } \\
\text { author } \\
\text { explains } \\
\text { whether he/she } \\
\text { pretest the } \\
\text { instruments? }\end{array}$ & $\begin{array}{l}\text { It was not possible to identify clear } \\
\text { descriptions of instruments pretesting. }\end{array}$ & $\begin{array}{l}\text { It was not possible to identify } \\
\text { clear descriptions of } \\
\text { instruments pretesting. }\end{array}$ & $\begin{array}{l}\text { It was not possible to identify } \\
\text { clear descriptions of } \\
\text { instruments pretesting. }\end{array}$ & $\begin{array}{l}\text { It was not possible to identify clear } \\
\text { descriptions of instruments pretesting. }\end{array}$ \\
\hline $\begin{array}{l}\text { Were the } \\
\text { strategies and } \\
\text { instruments of } \\
\text { data collection } \\
\text { selected } \\
\text { according to } \\
\text { the intended } \\
\text { research } \\
\text { objectives and } \\
\text { universe to be } \\
\text { investigated? }\end{array}$ & $\begin{array}{l}\text { There is indication that the study } \\
\text { constitutes a useful and appropriate } \\
\text { instrument to address the learning } \\
\text { process, and includes: } \\
\text { 1) reformulation of the teaching plan of } \\
\text { the discipline General Accountancy II; } \\
\text { 2) elaboration of a table comparing the } \\
\text { original and the reformulated plans; } \\
\text { 3) the selection of one of the units of the } \\
\text { teaching plan, and elaboration of a } \\
\text { detailed unit plan; } \\
\text { 4) definition of evaluation spreadsheets. }\end{array}$ & $\begin{array}{l}\text { There is indication that a } \\
\text { questionnaire with open } \\
\text { questions and close questions, } \\
\text { divided into } 5 \text { sections, was } \\
\text { elaborated. }\end{array}$ & $\begin{array}{l}\text { There is indication that an } \\
\text { in-depth interview was } \\
\text { conducted using a } \\
\text { questionnaire composed of } \\
\text { assertions and questions, } \\
\text { divided into } 4 \text { sections. }\end{array}$ & $\begin{array}{l}\text { In the abstract, there is indication that } \\
\text { the data were collected by } \\
\text { self-answerable printed questionnaires } \\
\text { personally applied in classroom. } \\
\text { In the methodology item, there is } \\
\text { indication that the printed questionnaire } \\
\text { was given to students to be answered in } \\
\text { the classroom, and that it is composed of } \\
\text { open and closed questions blocks, } \\
\text { according to the research objectives, and } \\
\text { that it was directly given by the authors } \\
\text { to the students in the classroom, from } \\
\text { April } 13 \text { to } 17,2009 \text {. }\end{array}$ \\
\hline $\begin{array}{l}\text { Does the } \\
\text { author explain } \\
\text { the methods } \\
\text { and techniques } \\
\text { used to analyze } \\
\text { and interpret } \\
\text { the data? }\end{array}$ & $\begin{array}{l}\text { It was not possible to identify clear } \\
\text { descriptions about the methods used } \\
\text { to analyze the data. }\end{array}$ & $\begin{array}{l}\text { It was not possible to } \\
\text { identify clear descriptions } \\
\text { about the methods used to } \\
\text { analyze the data. }\end{array}$ & $\begin{array}{l}\text { It was not possible to } \\
\text { identify clear descriptions } \\
\text { about the methods used to } \\
\text { analyze the data. }\end{array}$ & $\begin{array}{l}\text { In the abstract, there is indication that } \\
\text { the descriptive, and univariate and } \\
\text { bivariate statistical analyses were } \\
\text { conducted, such as the analysis of } \\
\text { the average difference test, analysis } \\
\text { of correlation matrix, and analysis } \\
\text { of correspondence. } \\
\text { In the methodology item, there is } \\
\text { information that the collected data } \\
\text { were processed and statistically } \\
\text { analyzed using a dedicated software. } \\
\text { The analysis method was the statistical } \\
\text { univariate and bivariate analysis. The } \\
\text { correspondence analysis technique } \\
\text { (ANACOR) was applied to visualize } \\
\text { the categories of users satisfied and } \\
\text { willing to use the VLE, in regard to } \\
\text { their influence position in the college } \\
\text { level environment. }\end{array}$ \\
\hline $\begin{array}{l}\text { Regarding the } \\
\text { methodological } \\
\text { rigor and } \\
\text { attainment of } \\
\text { the quality } \\
\text { standards of } \\
\text { the research }\end{array}$ & $\begin{array}{l}\text { As for the methodological aspects, we } \\
\text { notice limitations and the need of } \\
\text { adjustments, because authors (such as } \\
\text { Cervo \& Bervian; Silva, 2007; } \\
\text { Marconi \& Lakatos, 2010; Fachin, } \\
\text { 2003; Martins \& Theóphilo, 2009; } \\
\text { Bardin, 2004; Sampieri \& Collado, } \\
\text { 2006; Lúcio, 2006; Parra Filho \& } \\
\text { Santos, 2003) say that the methodology } \\
\text { of a research clears up the way to } \\
\text { achieve the results. } \\
\text { The authors explain that in order the } \\
\text { study becomes a useful instrument to } \\
\text { solve problems, it should characterize } \\
\text { the population, sample, as well as } \\
\text { report how and which were the } \\
\text { procedures used for the data collection } \\
\text { and analysis. Therefore, there would } \\
\text { be a commitment not only with the } \\
\text { methodological rigor, but also with } \\
\text { the quality of the research as a whole. }\end{array}$ & $\begin{array}{l}\text { We notice that there are still } \\
\text { failures because of the lack } \\
\text { of delimitation and } \\
\text { description of methods, } \\
\text { techniques and procedures } \\
\text { used. Authors (such as Cervo } \\
\text { \& Bervian; Silva, 2007; } \\
\text { Marconi \& Lakatos, 2010; } \\
\text { Fachin, 2003; Martins \& } \\
\text { Theóphilo, 2009; Bardin, } \\
\text { 2004; Sampieri \& Collado, } \\
\text { 2006; Lúcio, 2006; Parra } \\
\text { Filho \& Santos, 2003) inform } \\
\text { that in order a research attain } \\
\text { the methodological rigor, it } \\
\text { needs to make clear the } \\
\text { intentions, problematic and } \\
\text { method of conducting the } \\
\text { study. }\end{array}$ & $\begin{array}{l}\text { As for the methodological } \\
\text { aspects, we notice difficulties } \\
\text { and limitations, authors (such } \\
\text { as Cervo \& Bervian; Silva, } \\
\text { 2007; Marconi \& Lakatos, } \\
\text { 2010; Fachin, 2003; Martins } \\
\text { \& Theóphilo, 2009; Bardin, } \\
\text { 2004; Sampieri \& Collado, } \\
\text { 2006; Lúcio, 2006; Parra } \\
\text { Filho \& Santos, 2003) say } \\
\text { that the lack of attention to the } \\
\text { fundamental requirements } \\
\text { of the research jeopardizes } \\
\text { not only the methodological } \\
\text { rigor, but also the } \\
\text { fulfillment of the quality } \\
\text { standards of the research. }\end{array}$ & $\begin{array}{l}\text { As for the methodological aspects, } \\
\text { we notice difficulties and limitations, } \\
\text { authors (such as Cervo \& Bervian; } \\
\text { Silva, 2007; Marconi \& Lakatos, 2010; } \\
\text { Fachin, 2003; Martins \& Theóphilo, } \\
\text { 2009; Bardin, 2004; Sampieri \& } \\
\text { Collado, 2006; Lúcio, 2006; Parra Filho } \\
\text { \& Santos, 2003) highlight that the } \\
\text { methodological rigor somehow } \\
\text { fulfills the quality standards of } \\
\text { the research. }\end{array}$ \\
\hline
\end{tabular}

Source: Research data.

investigated researches. Data highlight fragilities in regard to the techniques and instruments of data collection and analysis; absence of delimitation and coverage of the research problem, and of the conditions to allow the work, as observed in the Table 3.

Upon analyzing the articles, object of this study, we have noticed that they lack improvements regarding the theoretical and methodological aspects. In regard the methodological aspects, authors such as Cervo and Bervian and Silva (2007); Marconi and Lakatos (2010); Fachin (2003); Martins and Theóphilo (2009); Bardin (2004); Sampieri, Collado and Lúcio (2006); Parra Filho and Santos (2003) describe that a research conducted with quality should present in its methodology which was the way they went through to conduct the work, in order another researcher could you it or even reapply it.

Inadequacies were verified in the fulfillment of fundamental 
requirements of a research, such as the formulation of the research problem. According to Bruyne et al. (1991), in the investigative process, the epistemology is the guarantee of the production of the scientific object and of the explanation of the problematic. However, the lack of adequacy and coherence between the title, the elaboration of objectives, as well the inexistence of a research issue, compromise the whole work, which does not have the required methodological rigor, and the quality standards required for a research.

In view of such information and of what authors such as Cervo, Bervian and Silva (2007), Marconi and Lakatos (2010), Fachin (2003), Martins and Theóphilo (2009), Luckesi et al. (2001), and Ferrari (1974) have pointed out, we noticed that there is still a certain way to go to attain the required rigor and quality. The scientific research should be the result of methodical and systemic investigations of the reality, through the classification, comparison, application of methods, analysis and synthesis. With such rigor, the researcher will extract the social context, or the context of the researched universe, principles and laws that structure a strictly valid and universal knowledge.

\section{Final Considerations}

This study had the aim of characterizing the scientific production on new technologies in the mediation of the accounting education, published in the EnANPAD and EnEPQ, in the period between 2005 and 2009, trying to identify epistemological aspects that could subsidize discussions about the scientific rigor and the fulfillment of quality standards of the scientific research related to the theme of new technologies in the accounting education.

We observed the concern of researchers regarding the importance of the use and acceptance of new technologies in teaching accountants. However, we also observed limitations and difficulties in terms of the theoretical-methodological rigor to be used in such researches, which can harm the relevance and usefulness of the developed studies.

We consider that the scientific research requires attention and competence, which develop along the researcher trajectory. We accept that the reduced number of analyzed articles is one of the limitations of this study, which does not allow us to make statements or take conclusions, but there is an effort to present suggestions and recommendations. As the main topics to be observed in future works, the following are the highlights:

1) Articulation between theme, problem, objectives, base theory of the study, and methodology;

2) Need of formulating the research problem as a fundamental requirement for the delimitation and deepening of the subject at issue;

3) Reflexive and critical dialogue between the studies conducted and the results found, in a process of categorization and dialectic union between theory and practice;

4) Theoretical consistence and disciplined, critical and broad bibliographic survey, in the state-of-the-art, about the investigated subject.

The feasibility of a scientific work relates to the conditions necessary to conduct the study, and to the empirical evidences that allow observations, tests, data collection and validations of possible findings of the investigation. We can also suggest the need of paying attention to the formulation of the problem proposition, including:

1) Relation between two or more variables that can be em- pirically tested, which should have a clear and well-delimited proposition;

2) Articulation between title, objective and theme of the study;

3) Fulfillment of the study relevance criterion;

4) Existence of a logical reasoning in writing the internal assumptions, making them unstable and difficult to prove.

Another important fact relates to the need of going back once again to the problem in the conclusions and results, to organize the discussions and attain the objectives fixed in the beginning of the investigation, otherwise they can be dispersed, or even proper results could not be attained. It is essential to pay attention to the aforementioned limitations and difficulties, because the inappropriate identification and formulation of a research problem might jeopardize its soundness, and even the validity of the investigation results.

We hope this study can contribute to deepening the knowledge and discussions about epistemological issues, more specifically regarding the methodological aspects that evidence the development stage, the scientific rigor and the fulfillment of the quality standards of the articles submitted to the events, thus allowing a higher contribution to the evolution of the accounting thought, more specifically the quality of the education and research in such field.

We conclude that inconsistencies of epistemological, theoretical and methodological nature do not contribute to making the scientific research an activity oriented towards the identification, analysis and problem-solving in different spheres of the knowledge.

As future researches, we suggest the conduction of bibliometric studies with more robust databases, which evidence the stage of thinking and its contributions for the enhancement of the research quality and of the teaching practice in the field of Accountancy.

\section{REFERENCES}

Andrade, C. S. (2002). O ensino de contabilidade introdutória nas universidades públicas do Brasil. Dissertação (Mestrado em Controladoria e Contabilidade), Universidade de São Paulo-USP, São Paulo.

http://www.ufpe.br/gepec/exemplos/03_dissertacao04(cacildaandrad e).pdf

Anpad (2010) Associação nacional de pós-graduação e pesquisa em administração. http://www.anpad.org.br/eventos.php

Audi, R. (2004). Dicionario akal de filosofia. Madrid: Akal.

Bardin, L. (2004). Análise de conteúdo (3rd ed.). Portugal: Edições.

Baxter, J., \& Chua, W. F. (2003). Alternative management accounting research whence and whiter. Accounting, Organizations and Society, 28, 97-126. http://dx.doi.org/10.1016/S0361-3682(02)00022-3

Brun, A. L., Dall'Asta, D., \& Dotto, M. L. G. (2010). Análise fácil: Ferramenta computacional de apoio ao ensino de análise de balanços. CAP Accounting and Management, 4, 69-79.

http://revistas.utfpr.edu.br/pb/index.php/CAP/article/viewFile/988/58 3

Bruyne, P., et al. (1991). Dinâmica da pesquisa em ciências sociais: Os polos da prática metodológica (5th ed.). Rio de Janeiro: Francisco Alves.

Bunge, M. (1980). Epistemologia: Curso de atualização. São Paulo: T. A. Queiroz/EDUSP

Carvalho Neto, S., \& Takaoka, H. (2009). Ambientes virtuais de aprendizagem de código livre como apoio ao ensino presencial na área de ciências sociais aplicadas: Um estudo de caso em uma instituição de Ensino Superior. In: Encontro nacional dos programas de pós-graduação em administração (pp. 1-16). São Paulo: EnANPAD. 
http://www.anpad.org.br/diversos/trabalhos/EnANPAD/enanpad_200 9/EPQ/2009_EPQ2923.pdf

Carvalho, A., et al. (2000). Aprendendo metodologia científica. São Paulo: O Nome da Rosa.

Chaves-Gamboa, M., \& Sánchez Gamboa, S. (2009) Pesquisa na educação física: Epistemologias, escola e formação profissional. Maceió: EdUFAL.

Cervo, A. L., Bervian, P. A., \& Silva, R. (2007). Metodologia científica (6. ed.). São Paulo: Pearson Prentice Hall.

Cornachione Jr., E. B. (2004). Tecnologia da educação e cursos de ciências Contábeis: Modelos colaborativos virtuais. Tese (LivreDocente), São Paulo: Universidade de São Paulo-USP.

http://www.teses.usp.br/teses/disponiveis/livredocencia/12/tde-12092 007-124732/

Coutinho, C. P., \& Bottentuit Jr., J. B. (2010). Utilização da técnica de brainstorming na introdução de um modelo de E/B-learning numa escola profissional portuguesa: A perspectiva de professores $e$ alunos. Madrid.

http://biblioteca.universia.net/html_bura/ficha/params/id/49416153.h tml

Devechi, C. P. V. (2008). Racionalidade comunicativa e a fundamentação da educação no contexto do pensamento pós-metafísico. Tese (Doutorado em Educação)—Programa de Pós-Graduação em Educação, Florianópolis, SC: Universidade Federal de Santa Catarina.

Eyerkaufer, M. L., Fietz, E. E., \& Domingues, M. J. (2006). Tecnologia da Informação no Ensino da Contabilidade: estudo realizado em duas instituições do estado de Santa Catarina. In: Simpósio de excelência em gestão e tecnologia. Resende, RJ: AEDB.

http://www.aedb.br/seget/artigos06/653_Artigo\%20Metodologia\%20 do\%20Ensino\%20para\%20SEGET.pdf

Fachin, O. (2003). Fundamentos de metodologia (4th ed.). São Paulo: Saraiva.

Feliu, V. M. R., \& Palanca, M. B. (2000). Desenvolvimento científico da contabilidade de gestão. Revista de Administração, 35, 98-106.

Ferrari, T. A. (1974). Metodologia da ciência (2nd ed.). Rio de Janeiro: Kennedy.

Ferrari, T. A. (1982). Metodologia da pesquisa. São Paulo: McGrawHill do Brasil.

Freitas, L. R. G. (2005). O curso de pedagogia e as novas tecnologias: Condições, limites e possibilidades para a formação de professores, a partir do olhar discente. Dissertação (Mestrado em Educação), Campinas: PUC-Campinas.

Gabriel, F., Pimentel, R. C., \& Martins, G. A. (2009). Epistemologia da pesquisa em contabilidade e finanças: Análises de plataformas teóricas no Brasil. In: Encontro brasileiro de finanças. São Leopoldo: Unisinos/RS

http://virtualbib.fgv.br/ocs/index.php/ebf/9EBF/paper/viewFile/688/1 67

Gianoto Jr., N., et al. (2007). O Papel da tecnologia da informação na formação do profissional de ciências contábeis: Um estudo sobre as percepções dos professores das IES da Cidade do Rio de Janeiro. In: Encontro de ensino e pesquisa em administração e contabilidade. Recife: EnEPQ.

Gomes, A. A. (2008). Considerações sobre a pesquisa científica: Em busca de caminhos para a pesquisa científica.

http://www.fct.unesp.br/Home/Departamentos/Educacao/AlbertoGo mes/aula_consideracoes-sobre-a-pesquisa.pdf

Gomes, A. A. (2003). Usos e possibilidades do grupo focal e outras alternativas metodológicas. Enfoques, 2, 1-8.

Gomes, M. Z., \& Gianoto Jr., N. (2007). A Contabilidade e as Novas Tecnologias de Informação: um estudo sobre as percepções dos estudantes de Graduação em Ciências Contábeis. In: Encontro de ensino e pesquisa em administração e contabilidade. Recife: EnEPQ.

Grinspun, M. P. S. Z. (1999). Educação tecnológica: Desafios e perspectivas. São Paulo: Cortez.

Guimarães, L. S. R. (2005). Novas tecnologias e mudanças no contexto de uma instituição educacional. In: J. Vigneron, \& V. B. Oliveira (Eds.), Sala de aula e tecnologias (pp. 15-28). São Bernardo do Campo: UMESP.

Hervada, J. (2008). Lecciones propedeuticas de filosofia del derecho (4th ed.). Navarra: Eunsa.

Kaplan, R. S. (1998). Inovation action research: Creating new management theory and practice. Journal of Management Accounting Research, 10, 89-118.

Kasanen, E., Lukka, K., \& Siitonen, A. (1993). The constructive approach in management accounting research. Journal of Management Accounting Research, 5, 242-264.

Keating, P. J. (1995). A Framework for classifying and evaluating the theoretical contribution of case research in management accounting. Journal of Management Accounting Research, 7, 66-86.

Lakatos, E. M., \& Marconi, M. A. (1991). Fundamentos de metodologia científica (3rd ed.). São Paulo: Atlas.

Lévy, P. (1999). A inteligência coletiva: Por uma antropologia do ciberespaço (2. ed.). São Paulo: Loyola.

Luckesi, C. C. (2005). Avaliação da aprendizagem na escola: Reelaborando conceitos e recriando a prática (2nd ed.). Salvador: Malabares.

Luckesi, C. C., et al. (2001). Fazer universidade: Uma proposta metodológica. São Paulo: Cortez.

Marconi, M. A., \& Lakatos, E. M. (2010). Fundamentos de Metodologia Científica (7th ed.). São Paulo: Atlas.

Martins, G. A., \& Theóphilo, C. R. (2009). Metodologia da investigação científica para ciências sociais aplicadas (2nd ed.). São Paulo: Atlas.

Masetto, M. T. (2003). Competência pedagógica do professor universitário. São Paulo: Summus.

Matias, M. A., et al. (2007). Análise epistemológica da produção científica em contabilidade sob a ótica da estruturação interna. In P. E. Anais (Ed.), Encontro de ensino e pesquisa em administração e contabilidade (p. 1). Recife/PE. Anais. Recife: EnEPQ.

Mattessich, R. (1996). Survey of accounting thought from 1946 to 1996. Asian-Pacific Journal of Accounting, 2, 140-148.

Minayo, M. C. S. (2008). Pesquisa social: Teoria, método e criatividade (27th ed.). Petrópolis: Vozes.

Mora, J. F. (1996). Dicionário de Filosofia. São Paulo: Martins Fontes.

Moran, J. M. (2000). Ensino e aprendizagem inovadores com tecnologia. Revista informática na educação: Teoria \& prática, PGIE/ UFRGS, 3, set.

http://www.seer.ufrgs.br/index.php/InfEducTeoriaPratica/article/vie w/6474/3862

Nascimento, A. R., Junqueira, E., \& Martins, G. A. (2009). Análise epistemológica da produção científica em contabilidade gerencial no Brasil. In Anais (Ed.), Encontro nacional dos programas de pósgraduação em administração, 33. São Paulo: EnANPAD.

Neves Jr., I. J., Medeiros, T. A., \& Batista, C. P. (2006). Aprendizagem cooperativa e tecnologia educacional na disciplina de contabilidade geral II do curso de ciências contábeis da universidade católica de Brasília—Em estilo salesiano de educar. In B. A. Anais (Ed.), Encontro nacional dos programas de pós-graduação em administração, 30. Salvador: EnANPAD.

Nonaka, I., \& Takeushi, H. (1997). Criação do conhecimento na empresa. Rio de Janeiro: Campus.

Nossa, S. N., Fiório, S. L., \& Sgarbi, A. D. (2006). Uma abordagem epistemológica da pesquisa contábil sobre balanço social e demonstração do valor adicionado. In Anais (Ed.), Congresso usp controladoria e contabilidade, 6, São Paulo: FEA/USP. Retrieved August 31, 2010 from http://www.congressousp.fipecafi.org/artigos62006/340.pdf

Parra Filho, D., \& Santos, J. A. (2003). Metodologia científica (6th ed.). São Paulo: Futura.

Pinsonneault, A., \& Kraemer, K. L. (1993). Survey research methodology in management information systems: Anassessment. Journal of Management Information Systems, 10, 75-105.

Porton, R. A. B., \& Loch, A. C. (2009). Abordagem epistemológica da pesquisa contábil no curso de ciências contábeis em uma instituição de ensino superior filiada ao sistema acafe. In S. C. Anais (Ed.), Congresso ufsc de controladoria e finanças e iniciação científica em contabilidade, 3, eletrônicos. Florianópolis: UFSC. http://dvl.ccn.ufsc.br/congresso/arquivos_artigos/artigos/564/200908 16181506.pdf 
Reis, J. B. A. (2009). O conceito de tecnologia e tecnologia educacional para alunos do ensino médio e superior. In Anais eletrônicos (Ed.), Congresso de leitura do Brasil, 17, 2009, Campinas: ALB.

http://www.alb.com.br/anais17/txtcompletos/sem16/COLE_932.pdf

Resende, A. L. (2003). Avaliação do ensino da contabilidade utilizando programa de simulação empresarial. 2003. 142 f. Dissertação (Mestrado em Ciências Contábeis)-UnB/UFPB/UFPE/UFRN, Brasília. Retrieved September 15, 2010 from

http://vsites.unb.br/cca/pos-graduacao/mestrado/dissertacoes/mest_di ssert_020.pdf

Ribeiro Filho, J. F., et al. (2007). Uma análise das abordagens epistemológicas e metodológicas da pesquisa contábil do programa do mestrado multiinstitucional em ciências contábeis. Revista Contabilidade Vista \& Revista, Belo Horizonte, 18.

http://www.face.ufmg.br/revista/index.php/contabilidadevistaerevista /article/viewFile/318/311

Rúdio, F. V. (1986). Introdução ao projeto de pesquisa científica. Petrópolis: Vozes.

Sampieri, R. H., Collado, C. F., \& Lucio, P. B. (2006). Metodologia de Pesquisa (3rd ed.). São Paulo: McGraw-Hill.

Sánchez Gamboa, S. (1989). A dialética na pesquisa em educação: elementos de contexto. In I. Fazenda (Ed.), Metodologia da pesquisa educacional (p. 93-115). São Paulo: Cortez.

Sánchez Gamboa, S. (2005). Epistemologia e Paradigma. In P. Fensterseifer et al. (Org.) (Eds.), Dicionário Crítico de Educação Física.
Ijuí: Unijuí.

Sánchez Gamboa, S. (2008). Pesquisa em educação: Métodos e epistemologias. Chapecó: Argós.

Santaella, L. (1996). Cultura das mídias (4th ed.). 2004. São Paulo: Experimento.

Santos, B. S. (1989). Introdução a uma Ciência Pós-moderna. Rio de Janeiro: Graal.

Sloczinski, H., \& Chiaramonte, M. S. (2005). Ambiente virtual: Interação e aprendizagem. Revista informática na educação: Teoria \& prática. Porto Alegre, 8, 71-88.

http://www.seer.ufrgs.br/index.php/InfEducTeoriaPratica/article/vie wFile/9631/5502

Theóphilo, C. R., \& de Iudícibus, S. (2005). Uma análise crítico-epistemológica da produção científica em contabilidade no Brasil. In Anais (Ed.), Encontro nacional dos programas de pós-graduação em administração, 29, Brasília: Enanpad.

Triviños, A. N. S. (2006). Introdução à pesquisa em ciências sociais. São Paulo: Atlas.

Young, S. M. (1999). Field research methods in management accounting. Accounting Horizons, 13, 76-84. http://dx.doi.org/10.2308/acch.1999.13.1.76

Zanchet, A. (2007). Problema de pesquisa: Uma análise empírica no curso de graduação em ciências contábeis. In Congresso usp controladoria e contabilidade, 7. São Paulo: FEA-USP. 